\title{
Prion Neurotoxicity: Insights from Prion Protein Mutants
}

\author{
Isaac H. Solomon ${ }^{1}$, Jessie A. Schepker ${ }^{1}$, \\ and David A. Harris* \\ Department of Cell Biology and Physiology \\ Washington University School of Medicine \\ St. Louis, MO 63110 USA
}

\begin{abstract}
The chemical nature of prions and the mechanism by which they propagate are now reasonably well understood. In contrast, much less is known about the identity of the toxic prion protein (PrP) species that are responsible for neuronal death, and the cellular pathways that these forms activate. In addition, the normal, physiological function of cellular $\operatorname{PrP}\left(\mathrm{PrP}^{\mathrm{C}}\right)$ has remained mysterious, hampering efforts to determine whether loss or alteration of this function contributes to the disease phenotype. Considerable evidence now suggests that aggregation, toxicity, and infectivity are distinct properties of PrP that do no necessarily coincide. In this review, we will discuss several mutant forms of PrP that produce spontaneous neurodegeneration in humans and/ or transgenic mice without the formation of infectious $\mathrm{PrPSc}$. These include an octapeptide insertional mutation, point mutations that favor synthesis of transmembrane forms of PrP, and deletions encompassing the central domain whose neurotoxicity is antagonized by the presence of wild-type PrP. By isolating the neurotoxic effects of PrP from the formation of infectious prions, these mutants have provided important insights into possible pathogenic mechanisms. These studies suggest that prion neurotoxicity may involve subversion of a cytoprotective activity of $\mathrm{PrP}^{\mathrm{C}}$ via altered signaling events at the plasma membrane.
\end{abstract}

\section{Introduction}

Prion diseases are fatal neurodegenerative illnesses of man and animals. This group of disorders includes CreutzfeldtJakob Disease (CJD), kuru, fatal familial insomnia (FFI), Gerstmann-Sträussler syndrome (GSS), and new variant CJD in humans, as well as bovine spongiform encephalopathy in cattle, chronic wasting disease in deer and elk, and scrapie in sheep and goats (Prusiner, 2004). Patients affected with these disorders suffer from dementia and ataxia, and often display spongiform degeneration and amyloid deposition in their brains.

A wealth of evidence suggests that the central molecular event in prion diseases is the conformational conversion of $\mathrm{PrP}^{\mathrm{C}}$, a normal cell-surface glycoprotein, into $\mathrm{PrP}^{\mathrm{Sc}}$, an abnormal isoform that is infectious in the absence of nucleic acid (Aguzzi et al., 2008; Prusiner, 1998). The precise structural differences between the two PrP isoforms remain to be defined, although it is clear that $\mathrm{PrP}^{\mathrm{Sc}}$ contains significantly more $\beta$-sheet and is more protease-resistant

\footnotetext{
${ }^{1}$ These two authors contributed equally to this work. *Current address: Department of Biochemistry, Boston University School of Medicine, 72 East Concord Street, K225, Boston, MA 02118 USA. E-mail: daharris@bu.edu
}

and aggregated than $\mathrm{PrP}^{\mathrm{C}}$. The conversion of $\mathrm{PrP}^{\mathrm{C}}$ to $\mathrm{PrP}^{\mathrm{Sc}}$ is thought to involve a templating mechanism in which the two forms physically interact.

Although we now have a detailed understanding of how prions propagate, the cellular mechanisms by which they kill neurons, and the toxic forms of PrP responsible, are poorly understood (Chiesa and Harris, 2001; Harris and True, 2006). Important insights into this issue have been obtained by analysis of PrP molecules carrying neurotoxic mutations. Several kinds of mutant PrP molecules induce spontaneous neurological illness in human beings or transgenic mice in the absence of infection from exogenous sources (Table 1 and Fig. 1). One category of such molecules are those carrying point or insertional mutations linked to human familial prion diseases. These mutants generally display $\mathrm{PrP}^{\mathrm{Sc}}$-like biochemical properties, and at least part of their pathogenicity is likely to depend on the toxic properties of the oligomeric protein aggregates that they form. A second category of mutations are those in the $\mathrm{N}$-terminal signal sequence and hydrophobic domain that influence the membrane topology of PrP. A third category includes a series of deletion mutations encompassing the central region of PrP that endow the protein with a powerful neurotoxic activity suppressible by co-expression of wild-type PrP. Mutants in the last two categories are not aggregated or protease-resistant, and their effects are likely due to alterations in a physiological activity of $\mathrm{PrP}^{\mathrm{C}}$.

Importantly, none of these three categories of mutations is accompanied by the formation of infectious $\mathrm{PrPSc}^{\mathrm{Sc}}$. By isolating the neurotoxic effects of PrP from the propagation of infectious prions, these mutants have made it possible to focus on pathogenic mechanisms underlying the disease process. Some of these mechanisms turn out to be surprisingly similar to those associated with non-infectious neurodegenerative disorders such as Alzheimer's disease.

In this article, we will discuss work from our laboratory utilizing each of these three categories of PrP mutants. As a prelude, we will first review what is currently known about the PrP forms and cellular pathways underlying prion neurotoxicity, as well as our current understanding of the physiological function of $\mathrm{PrPC}^{\mathrm{C}}$.

\section{Prion neurotoxicity: what is the toxic molecule?}

What form of PrP is responsible for killing neurons? It has commonly been assumed that $\mathrm{PrP}^{\mathrm{Sc}}$ itself is the primary cause of neurodegeneration, based on the temporal and anatomical correlation between the accumulation of this form and the development of neuropathological changes. However, there are a number of situations where this correlation is weak or absent. In several kinds of transmission experiments, for example, significant pathology and/or clinical dysfunction develop with little accumulation of $\mathrm{PrPSc}$ (Flechsig et al., 2000; Lasmezas et al., 1997; Manson et al., 1999). In addition, some familial prion diseases are not transmissible, and are not accompanied by the accumulation of protease resistant PrP (Brown et al., 1994b; Piccardo et al., 2001; Tateishi and Kitamoto, 1995; Tateishi et al., 1990; Tateishi et al., 1996). On the other hand, there are sub- 
Table 1. Properties of PrPC, PrPSc, and neurotoxic mutants of PrP

\begin{tabular}{|c|c|c|c|c|c|c|}
\hline Molecule & \begin{tabular}{|c|} 
Protease- \\
resistance/ \\
aggregation
\end{tabular} & $\begin{array}{l}\text { Cellular } \\
\text { localization }\end{array}$ & Infectivity & $\begin{array}{c}\text { Disease } \\
\text { onset (days) }\end{array}$ & Pathological targets & $\begin{array}{l}\text { Effect of wild-type PrP } \\
\text { (expression level) }\end{array}$ \\
\hline PrPC & - & PM/Rafts & - & N/A & None & N/A \\
\hline PrPSc & +++ & $\begin{array}{l}\text { PM, } \\
\text { endosomes }\end{array}$ & + & $\begin{array}{l}\text { Depends on } \\
\text { strain/host }\end{array}$ & Neurons, WM & Required \\
\hline PG14 Spon 1-3 & + & ER & - & 240 & $\begin{array}{l}\text { CGN, dendrites, } \\
\text { axons/myelin }\end{array}$ & No effect (1X) \\
\hline PG14 RML 1, 2 & +++ & Unknown & + & $\begin{array}{l}240 \text { (post- } \\
\text { inoculation) }\end{array}$ & CGN & Not tested \\
\hline $\begin{array}{l}\text { CtmPrP } \\
(\mathrm{L} 9 \mathrm{R} / 3 \mathrm{AV}))^{4-6}\end{array}$ & - & $\begin{array}{l}\text { ER (CHO } \\
\text { cells); Golgi } \\
\text { (neurons) }\end{array}$ & - & $85-172^{b}$ & CGN, HPN & Exacerbation (0.5-1X) \\
\hline $\operatorname{PrP} \Delta 32-121^{7}$ & - & Not tested & - & $42-56^{c}$ & CGN & Rescue (0.5X) \\
\hline $\operatorname{PrP} \Delta 32-134^{7}$ & - & PM & - & $21-35^{c}$ & CGN, WM & Rescue (0.5X) \\
\hline $\operatorname{PrP} \Delta 94-134^{8}$ & - & Rafts & - & $14^{\mathrm{c}}$ & WM & Rescue (2-3X) \\
\hline $\operatorname{PrP} \Delta 105-125^{9}$ & - & PM/Rafts & - & $7^{c}$ & CGN, WM & Rescue (5X) \\
\hline
\end{tabular}

Abbreviations: $\mathrm{CHO}$, Chinese hamster ovary; $\mathrm{CGN}$, cerebellar granule neurons; ER, endoplasmic reticulum; HPN, hippocampal neurons; N/A, not applicable; PM, plasma membrane; WM, white matter.

${ }^{a}$ Disease onset varies with transgene expression level. Data are for highest expressing lines (1-3X).

${ }^{b}$ For mice on the Prn- $p^{+/+}$background.

'For mice on the Prn- $p^{0 / 0}$ background.

References: ${ }^{1}$ Chiesa et al., 2003; ${ }^{2}$ Biasini et al., 2008; ${ }^{3}$ Jeffrey et al., 2009; ${ }^{4}$ Stewart et al., 2005; 5 Stewart and Harris, 2005;

${ }^{6}$ Stewart et al., 2001; ${ }^{7}$ Shmerling et al., 1998; ${ }^{8}$ Baumann et al., 2007; ${ }^{9}$ Li et al., $2007 \mathrm{~b}$.

clinical infections in which there is abundant $\mathrm{PrPSc}^{\mathrm{Sc}}$ but little symptomatology, for example after inoculation of hamster prions into mice (Hill et al., 2000; Race et al., 2001).

Taken together, these situations argue that $\mathrm{PrPSc}^{\mathrm{Sc}}$, the infectious form of PrP, may not be the proximate cause of neuronal dysfunction and degeneration in prion diseases. Several alternative forms of $\mathrm{PrP}$, distinct from both $\mathrm{PrP}^{\mathrm{C}}$ and $\mathrm{PrP}^{\mathrm{Sc}}$, have therefore been hypothesized to be the primary neurotoxic species (designated PrPtoxic). In subsequent sections, we will discuss two possible candidates for PrPtoxic (PG14 ${ }^{\text {spon }}$ and ${ }^{\mathrm{Ctm} P r P}$ ).

\section{Prion neurotoxicity: what are the cellular pathways?}

How do PrPSc or other toxic forms of PrP induce neuronal death? There is now a growing body of evidence that $\operatorname{Pr} P^{C}$, in addition to serving as a precursor of $\mathrm{PrP}^{\mathrm{Sc}}$, acts as a signal transducer or mediator of the neurotoxic effects of PrPSc (Harris and True, 2006). Support for this concept derives from several experimental situations in which expression of membrane-anchored $\mathrm{PrP}^{\mathrm{C}}$ in target neurons is essential for

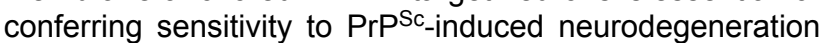
or toxicity. First, Prn- $p^{0 / 0}$ neurons are resistant to the pathologic effects of $\mathrm{PrP}^{\mathrm{Sc}}$ supplied from grafted brain tissue (Brandner et al., 1996) or from nearby astrocytes (Mallucci et al., 2003). Second, scrapie-inoculated mice expressing a glycolipid anchor-negative version of PrP develop minimal brain pathology and neurological dysfunction despite the accumulation of substantial amounts of $\mathrm{PrP}^{\mathrm{Sc}}$ amyloid (Chesebro et al., 2005). Although interpretation of this experiment is complicated by the relatively low expression levels of anchorless PrP in these mouse lines, one possible implication is that PrP must be membrane-anchored to efficiently mediate a toxic signal (Aguzzi, 2005). Third, $P r n-p^{0 / 0}$ neurons in culture have been found to be resistant to apoptosis induced by exposure to the synthetic peptide PrP106-126, which has been used as a model for PrPSc (Brown et al., 1994a). Finally, a recent study has shown that $\mathrm{PrP}^{\mathrm{C}}$ exerts a protective activity against cellular stress, and that $\mathrm{PrP}^{\mathrm{Sc}}$ abrogates this activity by activating stress-related signaling cascades (Rambold et al., 2008).

Combined with evidence that $\mathrm{PrP}^{\mathrm{C}}$ normally serves as a neuroprotective molecule (see below), these results taken together suggest a "subversion-of-function" hypothesis to explain prion-induced pathology (Harris and True, 2006): specifically, interaction with $\mathrm{PrP}^{\mathrm{Sc}}$ (or other pathogenic intermediates) alters a normal, physiological activity of $\mathrm{PrPC}$ in such a way that a neurotoxic stimulus is delivered. We will return to this mechanism later, when discussing the neurotoxicity of certain deleted forms of PrP.

\section{Function of $\operatorname{PrPC}$}

In order to specify how $\mathrm{PrPC}^{\mathrm{C}}$ function is altered or subverted in prion diseases, it is clearly essential to understand the normal, physiological role of the protein. Surprisingly, 

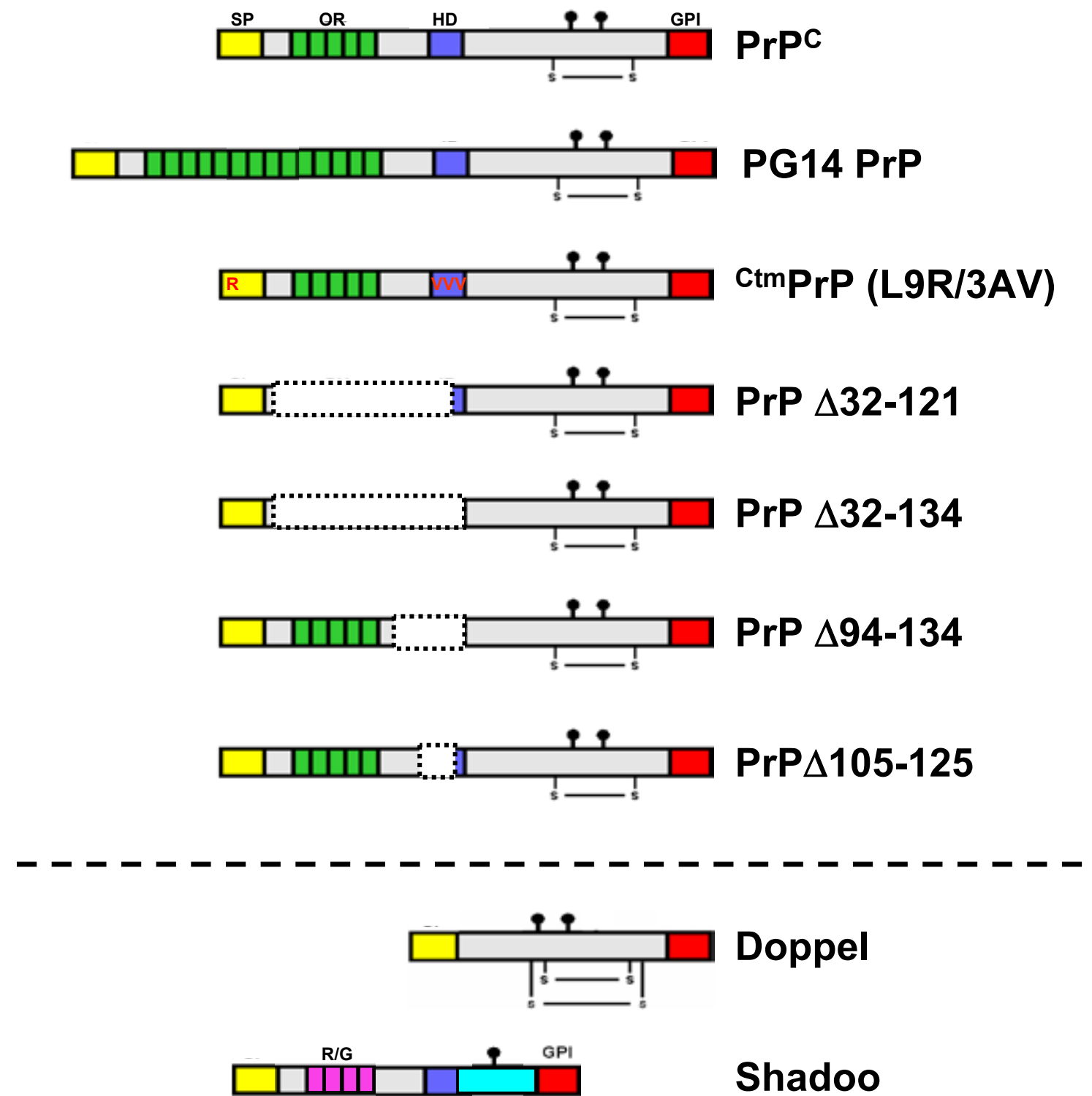

Shadoo

Figure 1. Schematic of wild-type and mutant PrP molecules, Doppel, and Shadoo. Structural domains are indicated by the colored blocks: SP (yellow), signal sequence; OR (green), octapeptide repeats; HD (blue), hydrophobic domain; GPI (red), glycosyl-phosphatidylinositol attachment signal; R/G (pink), arginine/glycine repeats of Sho. The lollipop symbols indicate sites of $\mathrm{N}$-linked glycosylation, and the S - S symbols indicate disulfide linkages.

however, twenty-five years since $\operatorname{PrP}^{\mathrm{C}}$ was first identified as an endogenous cellular protein, its physiological activity remains obscure (reviewed in Westergard et al., 2007). A variety of functions have been proposed, including roles in metal ion trafficking (Pauly and Harris, 1998), cell adhesion (Mange et al., 2002), and signal transduction (MouilletRichard et al., 2000). However, the evidence in favor of each of these hypothesized functions is not definitive.

Attempts to deduce the function of $\mathrm{PrPC}^{\mathrm{C}}$ from the phenotypes of PrP-null mice have been unrewarding. These mice display no major anatomical or developmental deficits, with the exception of lines in which the gene encoding Doppel (a PrP paralog) is artifactually up-regulated (Büeler et al.,
1992; Manson et al., 1994). Subtle phenotypic abnormalities have been described in PrP knock-out mice at the cellular or behavioral level, but some of these have been controversial, and in any case they have not provided an unambiguous clue to the biological function of $\operatorname{PrPC}^{C}$ (Steele et al., 2007). $A$ recent report suggests a role for $\mathrm{PrPC}^{\mathrm{C}}$ in embryonic cell adhesion, based on the phenotype of zebrafish in which expression of a PrP homologue has been knocked down (Malaga-Trillo et al., 2009). Whether this purported function is conserved in mammalian PrP remains to be determined.

Several intriguing lines of evidence have emerged recently suggesting that $\mathrm{PrPC}^{\mathrm{C}}$ may exert a cytoprotective activity, particularly against stresses (either internal or 
environmental) that initiate an apoptotic program (reviewed in Roucou et al., 2004; Roucou and LeBlanc, 2005). First, PrP over-expression rescues cultured neurons, some mammalian cell lines and yeast cells from pro-apoptotic stimuli, including Bax expression, serum withdrawal, and cytokine treatment (Bounhar et al., 2001; Diarra-Mehrpour et al., 2004; Kuwahara et al., 1999; Li and Harris, 2005; Roucou et al., 2005). Second, there is evidence that endogenous PrP protects cells against oxidative and pathologic stressors. For example, neurons cultured from $P r n-p^{0 / 0}$ mice display several subtle abnormalities related to increased susceptibility to oxidative stress (Brown et al., 2002). Moreover, after ischemic or traumatic brain injury, lesion size is larger in Prn- $p^{0 / 0}$ compared to wild-type mice (Hoshino et al., 2003; McLennan et al., 2004; SakuraiYamashita et al., 2005; Spudich et al., 2005). Finally, Prn-p $p^{0 / 0}$ mice are more susceptible to kainate-induced seizures (Rangel et al., 2007) and their retinal photoreceptors are more prone to light-induced degeneration (Frigg et al., 2006).

To explore the cytoprotective activity of $\mathrm{PrP}^{\mathrm{C}}$, we recently attempted to reproduce several of the published assays for this activity (Christensen and Harris, 2008). In one set of experiments, we found that PrP over-expression had a minimal effect on the death of MCF-7 breast carcinoma cells treated with TNF- $\alpha$, and on Prn- $p^{0 / 0}$ immortalized hippocampal neurons (HpL3-4 cells) subjected to serum deprivation. In a second set of assays, we observed only a small difference in viability between cerebellar granule neurons cultured from PrP-null and control mice in response to activation of endogenous or exogenous Bax. Although our results do not rule out a cytoprotective activity of $\mathrm{PrPC}$, they suggest that existing cell culture systems may be inadequate for modeling this activity.

\section{Mutant PrP molecules associated with inherited prion diseases}

Studies of mutant PrP molecules associated with inherited prion diseases have provided important clues to the molecular characteristics of PrPtoxic, and the mechanisms by which it is pathogenic. Approximately $10 \%$ of the cases of CJD and all cases of GSS and FFI are linked to dominantly inherited, germline mutations in the PrP gene on chromosome 20 (Mead, 2006). The mutations are presumed to favor spontaneous conversion of the protein to the PrPSc state without the necessity for contact with exogenous infectious agent. Point mutations occur in the C-terminal half of the PrP molecule, and are associated with either CJD, GSS or FFI. Insertional mutations, which are associated with a variable phenotype that can include features of CJD or GSS, consist of one to nine additional copies of a peptide repeat that is normally present in five copies in the N-terminal half of the protein.

A number of studies have used transfected cell lines to analyze the biochemical and cell biological properties of PrP molecules carrying disease-associated mutations (reviewed by Harris, 2003). These studies have revealed that some, but not all mutants, display $\mathrm{PrPS}^{\mathrm{S}}$-like biochemical properties including aggregation propensity as well as resistance to proteases and a GPI-specific phospholipase (Lehmann and Harris, 1996; Priola and Chesebro, 1998). Correlating with these abnormal biochemical properties, some mutants display altered subcellular localization, including partial retention in the ER (Ivanova et al., 2001), or retrotranslocation into the cytoplasm with subsequent degradation by the proteasome (Lorenz et al., 2002). Interestingly, some disease-associated PrP mutants are identical to wild-type PrP in terms of their biochemical properties and cellular distribution (Harris, 2003), raising the possibility that these molecules are pathogenic, not because they misfold and aggregate, but because the mutation subtly alters a physiological activity normally associated with $\mathrm{PrP}^{\mathrm{C}}$. Unfortunately, expression in transfected cells of PrP molecules carrying disease-associated mutations is generally not cytopathic, making it difficult to analyze the neurotoxic mechanisms underlying these mutants. For this reason, we and others have turned to transgenic models of familial prion diseases.

\section{A transgenic model of an octapeptide insertion: Tg(PG14) mice}

$\mathrm{Tg}$ (PG14) mice express the mouse homologue of a nineoctapeptide insertional PrP mutant associated with a familial prion disease of humans (Duchen et al., 1993; Krasemann et al., 1995; Owen et al., 1992) (Fig. 1). These animals display a spontaneous, progressive neurodegenerative disease with symptoms of ataxia, cerebellar granule cell loss, gliosis, and PrP deposition (Chiesa et al., 2000; Chiesa et al., 1998). $\mathrm{Tg}$ (PG14) mice spontaneously accumulate in their brains an insoluble and weakly protease-resistant form of the mutant protein (Chiesa et al., 2003). This form (designated PG14 ${ }^{\text {Spon }}$ ) is highly neurotoxic, but is not infectious in animal bioassays. In contrast, when $\mathrm{Tg}(\mathrm{PG} 14)$ mice are inoculated with the RML strain of prions, they accumulate a different form of PG14 PrP (designated PG14 ${ }^{\mathrm{RML}}$ ) that is highly protease-resistant and infectious in animal transmission experiments (Chiesa et al., 2003). Consistent with other published work, these studies emphasize that infectivity and pathogenicity are two distinct properties of PrP.

To gain insight into the molecular determinants of infectivity and pathogenicity, we have undertaken a biochemical characterization the biochemical properties of PG14 Spon and PG14 ${ }^{\mathrm{RML}}$. Our initial studies (Chiesa et al., 2003) indicated that these two forms, although conformationally related, differed in their quaternary structure, with $\mathrm{PG} 14^{\mathrm{RML}}$ forming larger, more tightly packed aggregates. We found that the majority of $P G 14^{\mathrm{RML}}$ aggregates have a sedimentation coefficient of $>50 S$, with $\sim 30 \%$ of them having a sedimentation coefficient of $>120$ S. If composed exclusively of $\mathrm{PrP}$, the latter aggregates would contain $>200$ molecules of the protein. In contrast, $15-20 \%$ of PG14 Spon PrP was monomeric (3.2S), with the rest sedimenting at 16-20S (corresponding to oligomers containing $\sim 20-30$ molecules of $\mathrm{PrP}$ ). These results suggest that while highly aggregated polymers of PrP are a prerequisite for prion infectivity, small, $\beta$-rich oligomers are the species that are toxic to nerve cells (Chiesa et al., 2003). This conclusion is strikingly reminiscent of recent work in Alzheimer's disease, which has demonstrated that small oligomers of the $A \beta$ peptide (ranging in size from 2-100 subunits), rather than large amyloid fibers, are the primary toxic species (Haass and Selkoe, 2007; Walsh and Selkoe, 2007).

In a more recent study (Biasini et al., 2008), we have subjected $\mathrm{PG} 14^{\text {Spon }}$ and $\mathrm{PG} 14^{\mathrm{RML}}$ to a panel of assays commonly used to distinguish infectious $\operatorname{PrP}$ 
$\left(\mathrm{PrP}^{\mathrm{Sc}}\right)$ from cellular $\operatorname{PrP}\left(\mathrm{PrP}^{\mathrm{C}}\right)$, including immobilized metal affinity chromatography, precipitation with sodium phosphotungstate, and immunoprecipitation with $\mathrm{PrPC}_{-}$

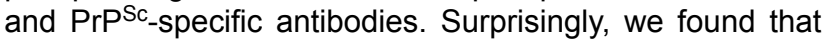
aggregates of PG14 $\mathrm{Spon}$ and $\mathrm{PG} 14^{\mathrm{RML}}$ behave identically to each other, and to authentic PrPSc, in each of these biochemical assays. PG14 Spon however, in contrast to $\mathrm{PG} 14^{\mathrm{RML}}$ and $\mathrm{PrPSc}$, was unable to seed the misfolding of $\mathrm{PrPC}^{\mathrm{C}}$ in an in vitro protein misfolding cyclic amplification reaction. Collectively, these results suggest that infectious and non-infectious aggregates of PrP share common structural features accounting for their toxicity, and that self-propagation of $\operatorname{PrP}$ involves more subtle molecular differences that remain to be identified.

\section{Gain vs. loss of function as a pathogenic mechanism}

How do mutant PrP molecules induce neurodegeneration? For most dominantly inherited neurodegenerative disorders, a gain-of-function mechanism is invoked in which the mutant protein is presumed to acquire a toxic property unrelated to its normal physiological activity (Winklhofer et al., 2008). For example, aggregates of the mutant protein could disrupt important cellular processes and so impair neuronal viability.

Such a mechanism appears to play a role in the pathogenicity of the PG14 PrP, based on our studies of the localization of this mutant in neurons in the brains of transgenic mice. We generated transgenic mice expressing PG14-EGFP, a fluorescent fusion protein that can be directly visualized in vivo (Medrano et al., 2008). Tg(PG14-EGFP) mice develop an ataxic neurological illness characterized by astrogliosis, PrP aggregation, and accumulation of a partially protease-resistant form of the mutant PrP. Strikingly, PG14-EGFP forms numerous fluorescent aggregates in the neuropil and white matter of multiple brain regions. These aggregates are particularly prominent along axonal tracts in both brain and peripheral nerve, and similar intracellular deposits are visible along the processes of cultured neurons. Our results suggest that intra-axonal aggregates of mutant PrP could contribute to the pathogenesis of familial prion disease by disrupting axonal transport. A similar mechanism of axonal blockage has recently been proposed to explain the pathogenesis of Alzheimer's disease (Stokin et al., 2005).

To investigate whether a loss-of-function mechanism could also play a role in the neurotoxicity of PG14 PrP, we crossed $\operatorname{Tg}(\mathrm{PG} 14)$ mice with $\operatorname{Tg}(\operatorname{PrP} \Delta 32-134)$ mice (Li et al., 2007c). $\operatorname{Tg}(\operatorname{PrP} \Delta 32-134)$ mice, which express an $\mathrm{N}$-terminally truncated form of PrP, spontaneously develop a neurodegenerative phenotype that is stoichiometrically reversed by co-expression of wild-type PrP. We found that, at equivalent expression levels, PG14 PrP is significantly less efficient than wild-type PrP in suppressing the development of clinical symptoms and neuropathology in $\operatorname{Tg}(\operatorname{PrP} \Delta 32-134)$ mice. Thus, our results suggest that some features of the neurological illness associated with inherited PrP mutations may be attributable to a loss of PrP neuroprotective function.

Since PrP-null mice do not display features of a prion disease (Büeler et al., 1992; Manson et al., 1994), it is unlikely that these disorders are due exclusively to the simple loss of an essential physiological function of $\operatorname{PrP}^{\mathrm{C}}$. A loss of function mechanism also appears to be incompatible with the dominant mode of inheritance of familial prion diseases. However, these facts do not rule out a contribution of PrP functional deficiency to prion-related neurodegeneration. For example, $\mathrm{PrP}^{\mathrm{Sc}}$ or mutant PrP may sequester wild-type $\mathrm{PrP}^{\mathrm{C}}$ into aggregates that lack functional activity, thereby producing a dominant-negative effect. Moreover a biological activity of $\mathrm{PrP}^{\mathrm{C}}$ that is dispensable under normal conditions may become essential in the disease state due to cellular or organismal stress.

Taken together, our results also indicate that more than one pathogenic mechanism (both gain- and loss-of-function) may contribute to neurotoxicity in inherited prion diseases.

\section{Topological variants of PrP}

There is evidence that alterations in membrane topology can result in neurotoxic forms of PrP. While most PrP molecules are linked to the plasma membrane exclusively via a GPI anchor, three topological variants have been described: CytoprP, NtmPrP, and CtmPrP (Chakrabarti et al., 2009). CytoprP, in which the polypeptide chain lies entirely in the cytoplasm, is produced at low levels as a result of inefficient translocation into the ER (Drisaldi et al., 2003). The amount of CytoPrP can be regulated by cellular stress, a mechanism that has been termed "pre-emptive quality control" (Kang et al., 2006). Mice expressing a transgenically encoded form of CytoprP show a severe neurodegenerative phenotype, indicating that this molecule possesses neurotoxic activity (Ma et al., 2002). It has been claimed that prion infection increases production of CytoprP (Rane et al., 2008), thereby contributing to neurotoxicity, but this observation is not confirmed by our own data (Stewart and Harris, 2003). At present, the pathogenic role of Cyto $\mathrm{PrP}$ in prion diseases remains unclear.

Two transmembrane variants of $\operatorname{PrP}$ have also been described. CtmPrP and NtmPrP span the lipid bilayer once via a stretch of hydrophobic amino acids in the central region of the protein (residues 111-135), with the $\mathrm{N}$ - or C-terminus, respectively, in the cytoplasm. These molecules were first observed in cell-free translation/translocation systems, where it was shown that their amounts could be altered by mutations in the central hydrophobic domain, as well as in an adjacent "stop transfer effector" segment that contains several positively charged amino acids (Hay et al., 1987; Hegde et al., 1998; Yost et al., 1990). Subsequent work from our laboratory (Stewart and Harris, 2003) and others (Kim et al., 2001) demonstrated that non-conservative substitutions in the core of the $\mathrm{N}$-terminal signal sequence also increased the proportion of ${ }^{\mathrm{Ctm}} \mathrm{PrP}$, and that combining these mutations with ones in the central domain resulted in almost exclusive synthesis of the CtmPrP. Cell biological analysis of one such compound mutant (L9R/3AV) (Fig. 1) led to the conclusion that ${ }^{\mathrm{tm} P r P}$ contains an uncleaved signal peptide as well as a GPI anchor, and that it is retained intracellularly in either the ER or the Golgi (depending on the cell type) (Stewart et al., 2001; Stewart and Harris, 2005).

Transgenic mice expressing PrP molecules with CtmPrPpromoting mutations display a neurodegenerative phenotype, implying that ${ }^{\mathrm{Ctm}} \mathrm{PrP}$ has neurotoxic potential in vivo (Hegde et al., 1998; Stewart et al., 2005). PrPSc accumulation has been claimed to cause enhanced generation of CtmPrP, and on this basis it has been suggested that CtmPrP represents a key neurotoxic intermediate in prion disorders (Hegde et al., 1999). However, this hypothesis is called into 
question by our observations that scrapie infection does not significantly alter CtmPrP levels in cultured cells or brain (Stewart and Harris, 2003), and that pathogenic mutations outside of the central, hydrophobic domain do not alter the membrane topology of PrP (Stewart and Harris, 2001).

Whether or not CtmPrP itself plays a role in naturally occurring prion diseases, it is likely to be revealing PrP-related neurotoxic signaling mechanisms that could contribute to the pathological process. Our studies of $\mathrm{Tg}(\mathrm{L} 9 \mathrm{R} / 3 \mathrm{AV})$ mice exemplify this point. These animals develop a fatal neurological illness characterized by ataxia and neuronal loss in the cerebellum and hippocampus (Stewart et al., 2005). Importantly, this phenotype is strongly dependent on co-expression of endogenous, wild-type PrP, suggesting a synergistic interaction between transmembrane and exclusively GPI-anchored forms of PrP in transducing a toxic signal.

\section{Neurotoxicity of PrP deletion mutants}

One of the most surprising and intriguing observations to have emerged concerning the neurotoxic effects of PrP was first made over 10 years ago by Shmerling et al. (1998) as part of a study to examine which parts of the PrP molecule were necessary for sustaining prion infection. These authors discovered that mice expressing PrP harboring either of two large, $\mathrm{N}$-terminal deletions $(\Delta 32-121$ and $\Delta 32-134)$ (Fig. 1) developed a spontaneous neurodegenerative illness even without inoculation with scrapie prions. This illness was characterized by ataxia and massive degeneration of cerebellar granule neurons. Mice with shorter deletions $(\Delta 32-80, \Delta 32-93, \Delta 32-106)$ were phenotypically normal, implying a critical role for amino acids distal to residue 106 . What was even more surprising, the neurodegenerative phenotype of the $\operatorname{Tg}(\Delta 32-121)$ and $\operatorname{Tg}(\Delta 32-134)$ mice was only observed on the Prn- $p^{0 / 0}$ background: co-expression of endogenous, wild-type PrP from even a single Prn- $p$ allele completely abrogated clinical symptoms and neuropathology. To explain these puzzling observations, the authors proposed a loss-of-function model based on the existence of two hypothetical molecules, one of which $\left(L_{p r p}\right)$ is a ligand that binds to $\operatorname{PrP}$ and the other $(\pi)$ a receptor that binds the ligand when PrP is absent. It was suggested that binding of $L_{\text {prp }}$ to wild-type PrP delivered an essential trophic signal, while binding to N-terminally deleted PrP failed to elicit this signal and also prevented interaction with $\pi$.

To more precisely map the region of $\operatorname{PrP}$ responsible for the spontaneous neurodegenerative phenotype, we created $\mathrm{Tg}(\Delta \mathrm{CR})$ mice expressing $\mathrm{PrP}$ with a much smaller deletion, comprising residues $105-125$ within the Central Region of the molecule (Li et al., 2007b) (Fig. 1). The deleted segment lies within a highly conserved, unstructured region of the protein, and encompasses a cluster of three positively charged amino acids (residues 105, 109, and 110) followed by a stretch of 15 hydrophobic residues (residues 111-135). There were three motivations for focusing on the 105-125 region as a possible toxicity-determining domain in PrP. First, the study by Shmerling et al. (1998) had pinpointed residues distal to position 106 as being critical determinants of neurotoxicity. Second, it was known that a synthetic peptide derived from this region (PrP106-126) was toxic when applied to cultured neurons from Prn- $p^{+/+}$but not from Prn- $p^{0 / 0}$ mice (Brown et al., 1994a). Third, the 105-125 region is one of the most highly conserved portions of the sequence, being virtually identical in PrP molecules from zebrafish to humans (Rivera-Milla et al., 2006).

$\mathrm{Tg}(\Delta \mathrm{CR})$ mice display a spontaneous neurodegenerative phenotype that is more severe than any we have ever encountered in other transgenic mice ( $\mathrm{Li}$ et al., 2007b). This phenotype is observed at modest expression levels of the mutant protein $(0.5-1 \mathrm{X})$. On the Prn- $p^{0 / 0}$ background, $\mathrm{Tg}(\Delta \mathrm{CR})$ mice become ill and die within one week of birth. This phenotype is reversed in a dose-dependent fashion by co-expression of wild-type PrP: one Prn-p allele (0.5X expression level) delays death until 25 days, and two Prn-p alleles (1X expression level) delays death until 48 days. The presence of one Tga20 allele (5X expression level of wild-type $\operatorname{PrP}$ ) strongly rescues the neurodegenerative phenotype, with mice remaining alive for well over one year.

$\mathrm{Tg}(\Delta \mathrm{CR})$ mice show two major kinds of neuropathology ( $\mathrm{Li}$ et al., 2007b). First, there is massive degeneration of cerebellar granule cells (with no effect on Purkinje cells), resulting in severe atrophy of the cerebellum. Degenerating granule neurons display extensive DNA fragmentation, but there is no activation of caspases 3 or 8 (Christensen et al., manuscript in preparation). By electron microscopy, granule cells display a unique, non-apoptotic ultrastructural morphology (Christensen et al., manuscript in preparation). In conjunction with evidence that neurodegeneration in $\mathrm{Tg}(\Delta \mathrm{CR})$ mice is Bax-independent ( $\mathrm{Li}$ et al., 2007a), our ultrastructural and biochemical data indicate that $\operatorname{PrP} \triangle C R$ is activating a novel form of neuronal death that is not related to apoptosis, necrosis, or autophagy.

The second major neuropathological feature of $\mathrm{Tg}(\Delta \mathrm{CR})$ mice is vacuolar degeneration of white matter areas of the brain and spinal cord, particularly in older animals. This abnormality, which was also seen $\operatorname{Tg}(\Delta 32-134)$ mice (Radovanovic et al., 2005), may be due either to axonal or myelin damage.

The biochemical and cell biological properties of $\operatorname{PrP} \Delta \mathrm{CR}$ suggest that the neurotoxicity of this molecule results from an alteration of a normal activity of $\mathrm{PrP}^{\mathrm{C}}$, rather than from accumulation of misfolded protein aggregates or cellular mislocalization. PrP $\triangle C R$ is not aggregated or protease-resistant like PrPSc (Li et al., 2007b). Moreover, the cellular localization of $\operatorname{PrP} \Delta C R$ is identical to that of wild-type PrP (Christensen and Harris, 2009). Like its wildtype counterpart, $\triangle \mathrm{CR} \operatorname{PrP}$ is present in lipid rafts on the plasma membrane, where it is attached by a GPI anchor, and it selectively localizes to the apical surface of polarized MDCK epithelial cells. Moreover, $\operatorname{PrP} \Delta C R$ is distributed in a punctate pattern on the surface of neuronal processes, similar to the wild-type protein.

Recently, Baumann et al. (Baumann et al., 2007) described lines of mice expressing PrP with a deletion of residues 94-134. These animals also display a neurodegenerative phenotype that is suppressible by coexpression of wild-type PrP. It is instructive to compare the features of mice expressing the four different pathogenic deletions thus far published $(\Delta 32-121, \Delta 32-134$, $\Delta 94-134$, and $\Delta 105-125$ ) (Fig. 1). Each of these deletions encompasses the $105-125$ region, demonstrating the importance of these residues in determining the neurotoxic activity of PrP. Interestingly, the four kinds of mice differ in the severity of the phenotypes they display (as indicated by age at symptom onset), and there is a correlation between 
the severity of the phenotype and the amount of wild-type PrP required for rescue (Table 1$)$. $\operatorname{Tg}(\Delta C R)$ mice, which have the strongest phenotype (illness onset at $<1$ week on the Prn- $p^{0 / 0}$ background), require $>5 \mathrm{X}$ expression of wildtype PrP for complete rescue, while $\operatorname{Tg}(\operatorname{PrP} \Delta 34-134)$ mice (illness onset at 3-5 weeks) are almost completely rescued by $0.5 \mathrm{X}$ co-expression of wild-type $\operatorname{PrP}$. This quantitative relationship between neurotoxic potency and the ability to be suppressed by wild-type PrP provides important clues to the underlying molecular mechanisms (see below).

\section{Doppel and shadoo}

Studies of two proteins with structural similarities to PrP have provided additional insights into the neurotoxic activities of PrP. Doppel (Dpl) is a PrP paralog that resembles the C-terminal half of PrP, but lacks residues homologous to the flexible N-terminal domain (Mo et al., 2001) (Fig. 1). Dpl thus structurally resembles the deleted forms of PrP that produce neurodegeneration in transgenic mice. The Dpl gene, which is normally expressed primarily in testis, is expressed ectopically in the brain in certain lines of $P r n-p^{0 / 0}$ mice as a result of intergenic splicing events between the adjacent PrP and Dpl genes (Moore et al., 1999). These lines, as well as transgenic lines expressing elevated levels of $\mathrm{Dpl}$ in the brain, display a neurodegenerative phenotype that is stoichiometrically rescued by wild-type PrP (Moore et al., 2001; Rossi et al., 2001). Dpl-induced neuronal death involves Purkinje cells as well as granule cells in the cerebellum, and is partially Bax-independent (Dong et al., 2007; Heitz et al., 2007). Taken together, the available data make it very likely that the neurotoxicity of Dpl involves the same molecular pathways as those activated by deleted forms of PrP.

While Dpl is structurally related to the C-terminal half of $\mathrm{PrP}$, the recently described protein, Shadoo (Sho), resembles a GPI-anchored version of the flexible, $\mathrm{N}$-terminal tail of PrP, including the highly conserved central region (reviewed in Watts and Westaway, 2007) (Fig. 1). Sho is expressed in many of the same regions of the brain as $\operatorname{PrPC}^{\mathrm{C}}$, although the cellular distribution of the two proteins is complementary (Watts et al., 2007). In the cerebellum, for example, Sho is most abundant in Purkinje cell bodies and dendrites, while $\mathrm{PrP}^{\mathrm{C}}$ is present at highest levels in granule neurons and their axons in the molecular layer. In a neuronal culture assay, Sho had no toxic activity on its own, but was able to suppress the toxicity of co-expressed Dpl and PrP $\Delta 32-121$ (Watts et al., 2007). Thus, Sho displays a neuroprotective activity like that of wild-type $\operatorname{PrP}^{\mathrm{C}}$. The protective activity of $\mathrm{PrPC}^{\mathrm{C}}$ presumably resides in the $\mathrm{N}$-terminal half of the protein, based on the observation that fusion of this region to Dpl prevents neurodegeneration in transgenic mice (Yoshikawa et al., 2008). Interestingly, Sho protein levels are dramatically down-regulated in scrapie-infected mice, raising the possibility that loss of Sho neuroprotection may play a role in prion diseases (Watts et al., 2007). It has been suggested that Sho is a candidate for $\pi$, the hypothetical receptor that has been postulated to deliver an essential neurotrophic signal in the absence of PrP (Watts et al., 2007).
A model for PrP neurotoxicity: subversion of function Studies of the biological activities of $\triangle C R$ and other deleted forms of PrP, along with $\mathrm{Dpl}$ and Sho, provide powerful mechanistic insights into the normal function of $\mathrm{PrP}^{\mathrm{C}}$, and how it can be subverted to produce neurotoxic effects. The dose-dependent, opposing effects of truncated and wildtype PrP are most easily explained by supposing that both proteins compete for binding to a common molecular target, with binding of truncated PrP eliciting a neurotoxic signal, and binding of wild-type PrP silencing the signal (or restoring a non-toxic, physiological signal) (Fig. 2). The molecular target for PrP is presumably a receptor or other cell-surface complex capable of transducing a signal to the interior of the cell. We hypothesize that binding to the target involves at least two sites on PrP: the CR region (residues 105-125), as well as a more $\mathrm{C}$-terminal region. In the absence of the $\mathrm{CR}$ region (as in $\operatorname{PrP} \Delta \mathrm{CR}$ ), binding of the C-terminal region alone would elicit a neurotoxic signal. Binding at both sites (wild-type PrP) would produce a physiological signal or no signal. We suggest that an identical mechanism is responsible for the neurotoxicity of all four deleted forms of PrP as well as Dpl, with variations in the toxic potency of these molecules being attributable to differences in their affinity for the putative binding target. The cytoprotective effect of Sho could be due to its ability to occupy the CR binding site on the putative transducer molecule.

Although $\triangle \mathrm{CR}$ and other deleted forms of PrP are artificial molecules, working out how they kill neurons will likely provide crucial insights into neurodegeneration in naturally occurring prion diseases. Like $\operatorname{PrP} \Delta C R$, PrPSc (or other toxic forms of PrP that accumulate during prion infection) appears to act by subverting a normal function of $\mathrm{PrPC}^{\mathrm{C}}$ (see above). It is therefore possible that $\mathrm{PrPS}^{\mathrm{S}}$ / PrPtoxic interacts with the same putative membrane target as $\operatorname{PrP} \triangle \mathrm{CR}$, resulting in generation of a similar neurotoxic signal (Fig. 2). Interestingly, there is evidence that $\mathrm{PrPSc}$ is conformationally altered in the CR region (Peretz et al, 1997), perhaps preventing binding interactions involving this site. Thus, $\operatorname{PrP}^{\mathrm{Sc}} / \mathrm{PrP}{ }^{\text {toxic }}$, like $\operatorname{PrP} \Delta \mathrm{CR}$, may be able to interact with its target only via C-terminal binding sites. The same may be true for PG14 PrP, which is aggregated and conformationally altered in the $\mathrm{CR}$ region (Biasini et al., 2008) (Fig. 2).

The model outlined here may also explain the toxicity of CtmPrP, as well as the synthetic peptide PrP106-126. PrP106-126 has been reported to be toxic to neurons cultured from Prn- $p^{+/+}$but not Prn- $p^{0 / 0}$ mice (Brown et al., 1994a; Fioriti et al., 2005; Forloni et al., 1993). This result suggests that the peptide alters interaction between $\operatorname{PrP}$ and the hypothetical transducer by competitively blocking binding within the 105-125 region of PrP. This would then produce a toxic signal equivalent to the one elicited by PrP $\triangle C R$ which lacks the 105-125 domain. In the absence of $\operatorname{PrPC}$, no signal would be delivered and the peptide would have no effect. In ${ }^{\mathrm{Ctm} P r P}$, the $\mathrm{CR}$ region is partially embedded in the lipid bilayer, and so would be unavailable for binding to the transducer (Fig. 2). In contrast to the situation for $\operatorname{PrP} \triangle \mathrm{CR}$, however, activation of the transducer by ${ }^{\mathrm{Ctm} P r P}$ is presumably facilitated by the presence of wildtype $\operatorname{PrP}$, which potentiates the toxicity of ${ }^{\mathrm{Ctm}} \mathrm{PrP}$. 


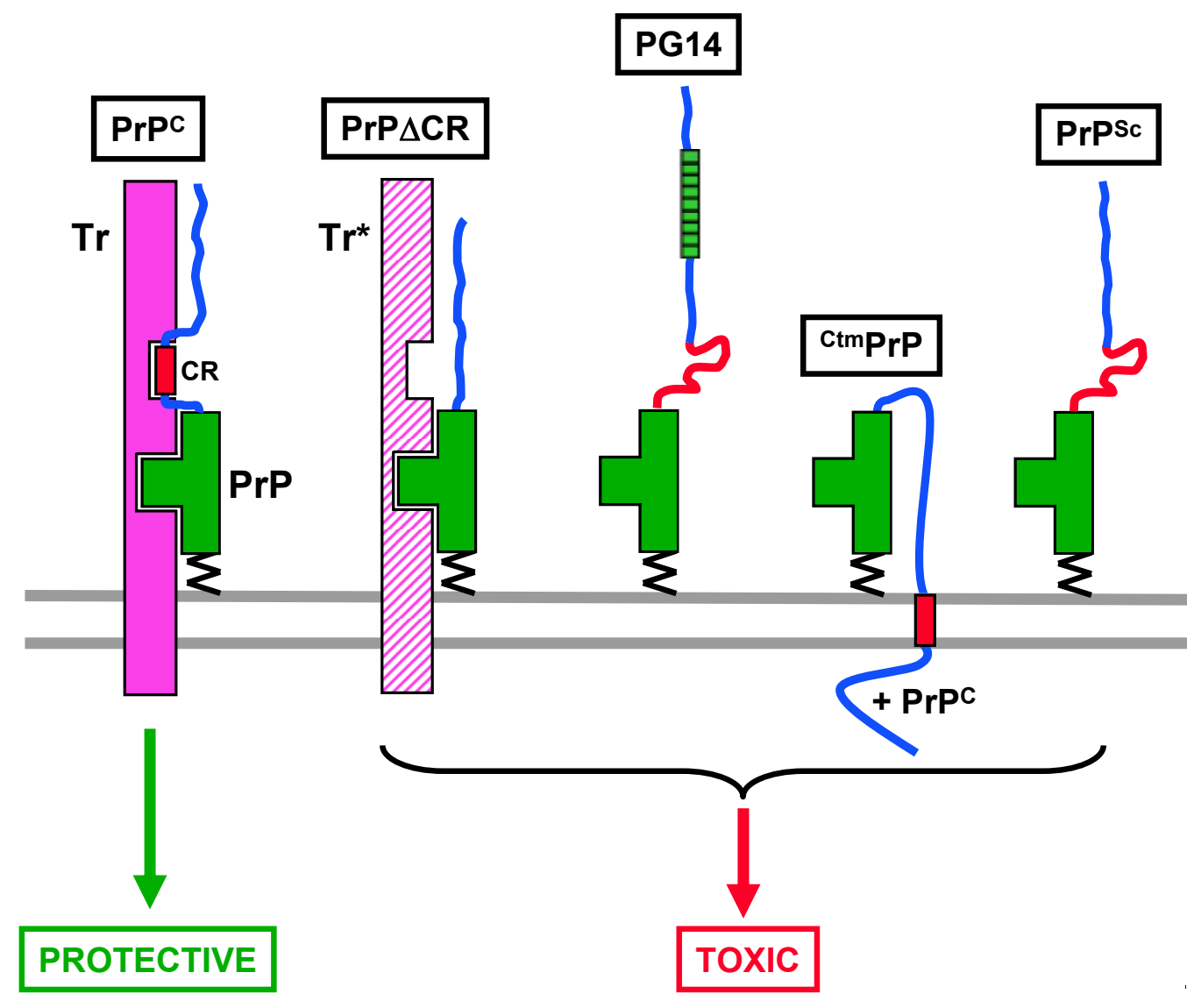

Figure 2. Model for the neuroprotective activity of $\operatorname{PrP}^{\mathrm{C}}$, and subversion of this activity by neurotoxic forms of $\mathrm{PrP}$. The structured, C-terminal half of PrP is shown in green and the flexible, N-terminal tail as a blue line. The CR segment of $\operatorname{PrP}$ (residues 105-125) is shown as a red rectangle. Tr, hypothetical signal transducing protein that normally generates a neuroprotective signal (solid pink), but which can assume an altered conformation (crosshatched pink) that generates a neurotoxic signal. Two binding sites between PrP and Tr are shown, one involving the C-terminal half of PrP and the other CR segment of PrP. When both binding sites are occupied, Tr elicits a non-essential neuroprotective signal $\left(\operatorname{Pr} \mathrm{P}^{\mathrm{C}}\right)$. When only the C-terminal site is occupied, as would be the case when the CR segment is absent (PrP $\Delta C R)$, embedded in the lipid bilayer ( ${ }^{\mathrm{Ctm} P r P}$ ), or conformationally altered (PG14 and $\mathrm{PrP}^{\mathrm{Sc}}$ ), the transducer delivers a neurotoxic signal. The toxicity of ${ }^{\mathrm{Ctm} P r P}$ requires the cooperation of wild-type $\mathrm{PrPC}^{\mathrm{C}}$.

\section{Conclusions and perspective}

Table 1 summarizes the properties of the non-infectious, neurotoxic mutants of $\operatorname{PrP}$ discussed in this review, and compares them to the properties of $\mathrm{PrPC}^{\mathrm{C}}$ and infectious $\mathrm{PrP}^{\mathrm{Sc}}$. Studies of neurotoxic PrP mutants have provided a number of important insights into the pathogenic species and cellular pathways that may underlie prion-induced neurodegeneration. An important principle exemplified by all of these mutants is the distinction between prion infectivity and neurotoxicity. For some of the mutants associated with familial prion disorders, such as octapeptide insertions, small, $\beta$-rich aggregates are likely to represent a key neurotoxic intermediate. There is evidence that these aggregates act via both gain- and loss-of-function mechanisms. In contrast, transmembrane mutants as well as mutants harboring deletions within the central region display biochemical and cell biological properties indistinguishable from those of wild-type PrP. The neurotoxicity of these mutants is likely to depend on alteration or subversion of a neuroprotective function of $\operatorname{PrPC}$.
Further understanding prion neurotoxicity will require progress on several fronts. First, it will be necessary to identify the molecular components of the cellular signaling pathways activated by neurotoxic forms of PrP. This will involve searching for PrP-interacting proteins via biochemical methods, as well as via genetic means using model organisms. The availability of highly potent neurotoxic forms like $\operatorname{PrP} \Delta \mathrm{CR}$ should facilitate this search, since these molecules should have an especially high affinity for putative cell surface transducers. Second, it will be important to develop cell culture systems that allow the neurotoxic effects of PrP to be studied in vitro. Unfortunately, the mutant PrP molecules discussed here, all of which are neurotoxic in transgenic mice, have only modest effects on cell viability when expressed in cultured cells (our unpublished data) (Ashok and Hegde, 2008; Drisaldi et al., 2004; Rambold et al., 2008; Watts et al., 2007). Presumably, some factor present in the brain milieu required for maximal toxicity of these molecules must be missing in cell culture 
systems. Finally, and perhaps most importantly, we will need to demonstrate a connection between the neurotoxic mechanisms activated by artificial mutants like PrP $\Delta C R$ and those operative in "natural" prion diseases of humans and animals. The most direct way to achieve this goal will be to knock down expression of the relevant signaling components in vivo, and see if this mitigates the disease phenotype.

Most current approaches to treatment of prion diseases are based on inhibiting accumulation of PrPSc (Trevitt and Collinge, 2006). Identification of the cellular pathways activated by neurotoxic forms of PrP would allow development of an entirely new class of anti-prion therapeutics based on blocking these pathways. Assuming appropriate cell culture models can be developed, some of the mutant forms of PrP described in this review may provide particularly good substrate for a drug screening approach to identify inhibitors of neurotoxic pathways. Such compounds may have wide applicability, given some of the underlying similarities between prion diseases and other neurodegenerative disorders in terms of pathogenic mechanisms. Indeed, recent evidence that $\mathrm{PrPC}^{\mathrm{C}}$ is a cellsurface receptor for the Alzheimer's $A \beta$ peptide provides a direct link between neurotoxic mechanisms involved in these two diseases (Laurén et al., 2009).

\section{Acknowledgements}

Work in the Harris laboratory is supported by grants from the National Institutes of Health (NS052526 and NS040975) and the Dana Foundation.

\section{References}

Aguzzi, A. (2005). Cell biology. Prion toxicity: all sail and no anchor. Science 308, 1420-1421.

Aguzzi, A., Baumann, F., and Bremer, J. (2008). The prion's elusive reason for being. Annu Rev Neurosci 31, 439-477.

Ashok, A., and Hegde, R.S. (2008). Retrotranslocation of prion proteins from the endoplasmic reticulum by preventing GPI signal transamidation. Mol Biol Cell 19, 3463-3476.

Baumann, F., Tolnay, M., Brabeck, C., Pahnke, J., Kloz, U., Niemann, H.H., Heikenwalder, M., Rülicke, T., Bürkle, A., and Aguzzi, A. (2007). Lethal recessive myelin toxicity of prion protein lacking its central domain. EMBO J 26, 538-547.

Biasini, E., Medrano, A.Z., Thellung, S., Chiesa, R., and Harris, D.A. (2008). Multiple biochemical similarities between infectious and non-infectious aggregates of a prion protein carrying an octapeptide insertion. $J$ Neurochem 104, 1293-1308.

Bounhar, Y., Zhang, Y., Goodyer, C.G., and LeBlanc, A. (2001). Prion protein protects human neurons against Baxmediated apoptosis. J Biol Chem 276, 39145-39149.

Brandner, S., Isenmann, S., Raeber, A., Fischer, M., Sailer, A., Kobayashi, Y., Marino, S., Weissmann, C., and Aguzzi, A. (1996). Normal host prion protein necessary for scrapie-induced neurotoxicity. Nature 379, 339-343.

Brown, D.R., Herms, J., and Kretzschmar, H.A. (1994a). Mouse cortical cells lacking cellular PrP survive in culture with a neurotoxic PrP fragment. Neuroreport 5, 2057-2060.
Brown, D.R., Nicholas, R.S., and Canevari, L. (2002). Lack of prion protein expression results in a neuronal phenotype sensitive to stress. J Neurosci Res 67, 211-224.

Brown, P., Gibbs, C.J., Rodgers-Johnson, P., Asher, D.M., Sulima, M.P., Bacote, A., Goldfarb, L.G., and Gajdusek, D.C. (1994b). Human spongiform encephalopathy: the National Institutes of Health series of 300 cases of experimentally transmitted disease. Ann Neurol 35, 513-529.

Büeler, H., Fischer, M., Lang, Y., Fluethmann, H., Lipp, H.-P., DeArmond, S.J., Prusiner, S.B., Aguet, M., and Weissmann, C. (1992). Normal development and behavior of mice lacking the neuronal cell-surface PrP protein. Nature 356, 577-582.

Chakrabarti, O., Ashok, A., and Hegde, R.S. (2009). Prion protein biosynthesis and its emerging role in neurodegeneration. Trends Biochem Sci doi:10.1016/j. tibs.2009.03.001.

Chesebro, B., Trifilo, M., Race, R., Meade-White, K., Teng, C., LaCasse, R., Raymond, L., Favara, C., Baron, G., Priola, S., et al. (2005). Anchorless prion protein results in infectious amyloid disease without clinical scrapie. Science 308, 1435-1439.

Chiesa, R., Drisaldi, B., Quaglio, E., Migheli, A., Piccardo, P., Ghetti, B., and Harris, D.A. (2000). Accumulation of protease-resistant prion protein $(\mathrm{PrP})$ and apoptosis of cerebellar granule cells in transgenic mice expressing a PrP insertional mutation. Proc Natl Acad Sci USA 97, 5574-5579.

Chiesa, R., and Harris, D.A. (2001). Prion diseases: what is the neurotoxic molecule? Neurobiol Dis 8, 743-763.

Chiesa, R., Piccardo, P., Ghetti, B., and Harris, D.A. (1998). Neurological illness in transgenic mice expressing a prion protein with an insertional mutation. Neuron 21, 1339-1351.

Chiesa, R., Piccardo, P., Quaglio, E., Drisaldi, B., Si-Hoe, S.L., Takao, M., Ghetti, B., and Harris, D.A. (2003). Molecular distinction between pathogenic and infectious properties of the prion protein. J Virol 77, 7611-7622.

Christensen, H.M., and Harris, D.A. (2008). Prion protein lacks robust cytoprotective activity in cultured cells. Mol Neurodegener 3, 11.

Christensen, H.M., and Harris, D.A. (2009). A deleted prion protein that is neurotoxic in vivo is localized normally in cultured cells. J Neurochem 108, 44-56.

Diarra-Mehrpour, M., Arrabal, S., Jalil, A., Pinson, X., Gaudin, C., Pietu, G., Pitaval, A., Ripoche, H., Eloit, M., Dormont, D., et al. (2004). Prion protein prevents human breast carcinoma cell line from tumor necrosis factor alpha-induced cell death. Cancer Res 64, 719-727.

Dong, J., Li, A., Yamaguchi, N., Sakaguchi, S., and Harris, D.A. (2007). Doppel induces degeneration of cerebellar Purkinje cells independently of Bax. Am J Pathol 171, 599-607.

Drisaldi, B., Coomaraswamy, J., Mastrangelo, P., Strome, B., Yang, J., Watts, J.C., Chishti, M.A., Marvi, M., Windl, O., Ahrens, R., et al. (2004). Genetic mapping of activity determinants within cellular prion proteins: $\mathrm{N}$-terminal modules in $\mathrm{PrP}^{\mathrm{C}}$ offset pro-apoptotic activity of the Doppel helix B/B' region. J Biol Chem 279, 55443-55454.

Drisaldi, B., Stewart, R.S., Adles, C., Stewart, L.R., Quaglio, E., Biasini, E., Fioriti, L., Chiesa, R., and Harris, D.A. (2003). Mutant PrP is delayed in its exit from the 
endoplasmic reticulum, but neither wild-type nor mutant PrP undergoes retrotranslocation prior to proteasomal degradation. J Biol Chem 278, 21732-21743.

Duchen, L.W., Poulter, M., and Harding, A.E. (1993). Dementia associated with a 216 base pair insertion in the prion protein gene: clinical and neuropathological features. Brain 116, 555-567.

Fioriti, L., Quaglio, E., Massignan, T., Colombo, L., Stewart, R.S., Salmona, M., Harris, D.A., Forloni, G., and Chiesa, R. (2005). The neurotoxicity of prion protein $(\operatorname{PrP})$ peptide 106-126 is independent of the expression level of PrP and is not mediated by abnormal PrP species. Mol Cell Neurosci 28, 165-176.

Flechsig, E., Shmerling, D., Hegyi, I., Raeber, A.J., Fischer, M., Cozzio, A., von Mering, C., Aguzzi, A., and Weissmann, C. (2000). Prion protein devoid of the octapeptide repeat region restores susceptibility to scrapie in PrP knockout mice. Neuron 27, 399-408.

Forloni, G., Angeretti, N., Chiesa, R., Monzani, E., Salmona, M., Bugiani, O., and Tagliavini, F. (1993). Neurotoxicity of a prion protein fragment. Nature $362,543-546$.

Frigg, R., Wenzel, A., Samardzija, M., Oesch, B., Wariwoda, H., Navarini, A.A., Seeliger, M.W., Tanimoto, N., Reme, C., and Grimm, C. (2006). The prion protein is neuroprotective against retinal degeneration in vivo. Exp Eye Res 83, 1350-1358.

Haass, C., and Selkoe, D.J. (2007). Soluble protein oligomers in neurodegeneration: lessons from the Alzheimer's amyloid beta-peptide. Nat Rev Mol Cell Biol 8, 101-112.

Harris, D.A. (2003). Trafficking, turnover and membrane topology of PrP. Br Med Bull 66, 71-85.

Harris, D.A., and True, H.L. (2006). New insights into prion structure and toxicity. Neuron 50, 353-357.

Hay, B., Barry, R.A., Lieberburg, I., Prusiner, S.B., and Lingappa, V.R. (1987). Biogenesis and transmembrane orientation of the cellular isoform of the scrapie prion protein. Mol Cell Biol 7, 914-920.

Hegde, R.S., Mastrianni, J.A., Scott, M.R., Defea, K.A., Tremblay, P., Torchia, M., DeArmond, S.J., Prusiner, S.B., and Lingappa, V.R. (1998). A transmembrane form of the prion protein in neurodegenerative disease. Science 279 , 827-834.

Hegde, R.S., Tremblay, P., Groth, D., DeArmond, S.J., Prusiner, S.B., and Lingappa, V.R. (1999). Transmissible and genetic prion diseases share a common pathway of neurodegeneration. Nature 402, 822-826.

Heitz, S., Lutz, Y., Rodeau, J.L., Zanjani, H., Gautheron, V., Bombarde, G., Richard, F., Fuchs, J.P., Vogel, M.W., Mariani, J., et al. (2007). BAX contributes to Doppelinduced apoptosis of prion-protein-deficient Purkinje cells. Dev Neurobiol 67, 670-686.

Hill, A.F., Joiner, S., Linehan, J., Desbruslais, M., Lantos, P.L., and Collinge, J. (2000). Species-barrier-independent prion replication in apparently resistant species. Proc Natl Acad Sci USA 97, 10248-10253.

Hoshino, S., Inoue, K., Yokoyama, T., Kobayashi, S., Asakura, T., Teramoto, A., and Itohara, S. (2003). Prions prevent brain damage after experimental brain injury: a preliminary report. Acta Neurochir Suppl 86, 297-299.

Ivanova, L., Barmada, S., Kummer, T., and Harris, D.A. (2001). Mutant prion proteins are partially retained in the endoplasmic reticulum. J Biol Chem 276, 42409-42421.
Jeffrey, M., Goodsir, C.M., McGovern, G., Barmada, S., Medrano, A.Z., and Harris, D.A. (2009). Prion protein with an insertional mutation accumulates on axonal and dendritic

plasmalemma, and is associated with distinctive ultrastructural changes. Am J Pathol In Press.

Kang, S.W., Rane, N.S., Kim, S.J., Garrison, J.L., Taunton, J., and Hegde, R.S. (2006). Substrate-specific translocational attenuation during ER stress defines a pre-emptive quality control pathway. Cell 127, 999-1013.

Kim, S.J., Rahbar, R., and Hegde, R.S. (2001). Combinatorial control of prion protein biogenesis by the signal sequence and transmembrane domain. J Biol Chem 276, 26132-26140.

Krasemann, S., Zerr, I., Weber, T., Poser, S., Kretzschmar, H., Hunsmann, G., and Bodemer, W. (1995). Prion disease associated with a novel nine octapeptide repeat insertion in the PRNP gene. Mol Brain Res 34, 173-176.

Kuwahara, C., Takeuchi, A.M., Nishimura, T., Haraguchi, K., Kubosaki, A., Matsumoto, Y., Saeki, K., Yokoyama, T., Itohara, S., and Onodera, T. (1999). Prions prevent neuronal cell-line death. Nature 400, 225-226.

Lasmezas, C.I., Deslys, J.P., Robain, O., Jaegly, A., Beringue, V., Peyrin, J.M., Fournier, J.G., Hauw, J.J., Rossier, J., and Dormont, D. (1997). Transmission of the BSE agent to mice in the absence of detectable abnormal prion protein. Science 275, 402-405.

Laurén, J., Gimbel, D.A., Nygaard, H.B., Gilbert, J.W., and Strittmatter, S.M. (2009). Cellular prion protein mediates impairment of synaptic plasticity by amyloid-beta oligomers. Nature 457, 1128-1132.

Lehmann, S., and Harris, D.A. (1996). Mutant and infectious prion proteins display common biochemical properties in cultured cells. J Biol Chem 271, 1633-1637.

Li, A., Barmada, S.J., Roth, K.A., and Harris, D.A. (2007a). $\mathrm{N}$-terminally deleted forms of the prion protein activate both Bax-dependent and Bax-independent neurotoxic pathways. J Neurosci 27, 852-859.

Li, A., Christensen, H.M., Stewart, L.R., Roth, K.A., Chiesa, R., and Harris, D.A. (2007b). Neonatal lethality in transgenic mice expressing prion protein with a deletion of residues 105-125. EMBO J 26, 548-558.

$\mathrm{Li}, \mathrm{A}$., and Harris, D.A. (2005). Mammalian prion protein suppresses Bax-induced cell death in yeast. J Biol Chem 280, 17430-17434.

Li, A., Piccardo, P., Barmada, S.J., Ghetti, B., and Harris, D.A. (2007c). Prion protein with an octapeptide insertion has impaired neuroprotective activity in transgenic mice. EMBO J 26, 2777-2785.

Lorenz, H., Windl, O., and Kretzschmar, H.A. (2002). Cellular phenotyping of secretory and nuclear prion proteins associated with inherited prion diseases. J Biol Chem 277, 8508-8516.

Ma, J., Wollmann, R., and Lindquist, S. (2002). Neurotoxicity and neurodegeneration when PrP accumulates in the cytosol. Science 298, 1781-1785.

Malaga-Trillo, E., Solis, G.P., Schrock, Y., Geiss, C., Luncz, L., Thomanetz, V., and Stuermer, C.A. (2009). Regulation of embryonic cell adhesion by the prion protein. PLoS Biol 7, e55.

Mallucci, G., Dickinson, A., Linehan, J., Klohn, P.C., Brandner, S., and Collinge, J. (2003). Depleting neuronal $\mathrm{PrP}$ in prion infection prevents disease and reverses spongiosis. Science 302, 871-874. 
Mange, A., Milhavet, O., Umlauf, D., Harris, D., and Lehmann, S. (2002). PrP-dependent cell adhesion in N2a neuroblastoma cells. FEBS Lett 514, 159-162.

Manson, J.C., Clarke, A.R., Hooper, M.L., Aitchison, L., McConnell, I., and Hope, J. (1994). 129/Ola mice carrying a null mutation in PrP that abolishes mRNA production are developmentally normal. Mol Neurobiol 8, 121-127.

Manson, J.C., Jamieson, E., Baybutt, H., Tuzi, N.L., Barron, R., McConnell, I., Somerville, R., Ironside, J., Will, R., Sy, M.S., et al. (1999). A single amino acid alteration (101L) introduced into murine PrP dramatically alters incubation time of transmissible spongiform encephalopathy. EMBO J 18, 6855-6864.

McLennan, N.F., Brennan, P.M., McNeill, A., Davies, I., Fotheringham, A., Rennison, K.A., Ritchie, D., Brannan, F., Head, M.W., Ironside, J.W., et al. (2004). Prion protein accumulation and neuroprotection in hypoxic brain damage. Am J Pathol 165, 227-235.

Mead, S. (2006). Prion disease genetics. Eur J Hum Genet 14, 273-281.

Medrano, A.Z., Barmada, S.J., Biasini, E., and Harris, D.A. (2008). GFP-tagged mutant prion protein forms intraaxonal aggregates in transgenic mice. Neurobiol Dis 31, 20-32.

Mo, H., Moore, R.C., Cohen, F.E., Westaway, D., Prusiner, S.B., Wright, P.E., and Dyson, H.J. (2001). Two different neurodegenerative diseases caused by proteins with similar structures. Proc Natl Acad Sci USA 98, 2352-2357.

Moore, R.C., Lee, I.Y., Silverman, G.L., Harrison, P.M., Strome, R., Heinrich, C., Karunaratne, A., Pasternak, S.H., Chishti, M.A., Liang, Y., et al. (1999). Ataxia in prion protein (PrP)-deficient mice is associated with upregulation of the novel PrP-like protein doppel. J Mol Biol 292, 797-817.

Moore, R.C., Mastrangelo, P., Bouzamondo, E., Heinrich, C., Legname, G., Prusiner, S.B., Hood, L., Westaway, D., DeArmond, S.J., and Tremblay, P. (2001). Doppelinduced cerebellar degeneration in transgenic mice. Proc Natl Acad Sci USA 98, 15288-15293.

Mouillet-Richard, S., Ermonval, M., Chebassier, C., Laplanche, J.L., Lehmann, S., Launay, J.M., and Kellermann, O. (2000). Signal transduction through prion protein. Science 289, 1925-1928.

Owen, F., Poulter, M., Collinge, J., Leach, M., Lofthouse, R., Crow, T.J., and Harding, A.E. (1992). A dementing illness associated with a novel insertion in the prion protein gene. Mol Brain Res 13, 155-157.

Pauly, P.C., and Harris, D.A. (1998). Copper stimulates endocytosis of the prion protein. J Biol Chem 273, 33107-33110.

Piccardo, P., Liepnieks, J.J., William, A., Dlouhy, S.R., Farlow, M.R., Young, K., Nochlin, D., Bird, T.D., Nixon, R.R., Ball, M.J., et al. (2001). Prion proteins with different conformations accumulate in Gerstmann-SträusslerScheinker disease caused by A117V and F198S mutations. Am J Pathol 158, 2201-2207.

Priola, S.A., and Chesebro, B. (1998). Abnormal properties of prion protein with insertional mutations in different cell types. J Biol Chem 273, 11980-11985.

Prusiner, S.B. (1998). Prions. Proc Natl Acad Sci USA 95, 13363-13383.
Prusiner, S.B., ed. (2004). Prion Biology and Diseases, Second edn (Cold Spring Harbor, New York, Cold Spring Harbor Laboratory Press).

Race, R., Raines, A., Raymond, G.J., Caughey, B., and Chesebro, B. (2001). Long-term subclinical carrier state precedes scrapie replication and adaptation in a resistant species: analogies to bovine spongiform encephalopathy and variant Creutzfeldt-Jakob disease in humans. J Virol 75, 10106-10112.

Radovanovic, I., Braun, N., Giger, O.T., Mertz, K., Miele, G., Prinz, M., Navarro, B., and Aguzzi, A. (2005). Truncated prion protein and Doppel are myelinotoxic in the absence of oligodendrocytic PrPC . J Neurosci 25, 4879-4888.

Rambold, A.S., Muller, V., Ron, U., Ben-Tal, N., Winklhofer, K.F., and Tatzelt, J. (2008). Stress-protective signalling of prion protein is corrupted by scrapie prions. EMBO $\mathrm{J} 27$, 1974-1984.

Rane, N.S., Kang, S.W., Chakrabarti, O., Feigenbaum, L., and Hegde, R.S. (2008). Reduced translocation of nascent prion protein during ER stress contributes to neurodegeneration. Dev Cell 15, 359-370.

Rangel, A., Burgaya, F., Gavin, R., Soriano, E., Aguzzi, A., and Del Rio, J.A. (2007). Enhanced susceptibility of Prnp-deficient mice to kainate-induced seizures, neuronal apoptosis, and death: Role of AMPA/kainate receptors. J Neurosci Res 85, 2741-2755.

Rivera-Milla, E., Oidtmann, B., Panagiotidis, C.H., Baier, M., Sklaviadis, T., Hoffmann, R., Zhou, Y., Solis, G.P., Stuermer, C.A., and Malaga-Trillo, E. (2006). Disparate evolution of prion protein domains and the distinct origin of Doppel- and prion-related loci revealed by fish-tomammal comparisons. FASEB J 20, 317-319.

Rossi, D., Cozzio, A., Flechsig, E., Klein, M.A., Rülicke, T., Aguzzi, A., and Weissmann, C. (2001). Onset of ataxia and Purkinje cell loss in PrP null mice inversely correlated with Dpl level in brain. EMBO J 20, 694-702.

Roucou, X., Gains, M., and LeBlanc, A.C. (2004). Neuroprotective functions of prion protein. J Neurosci Res 75, 153-161.

Roucou, X., Giannopoulos, P.N., Zhang, Y., Jodoin, J., Goodyer, C.G., and LeBlanc, A. (2005). Cellular prion protein inhibits proapoptotic Bax conformational change in human neurons and in breast carcinoma MCF-7 cells. Cell Death Differ 12, 783-795.

Roucou, X., and LeBlanc, A.C. (2005). Cellular prion protein neuroprotective function: implications in prion diseases. $J$ Mol Med 83, 3-11.

Sakurai-Yamashita, Y., Sakaguchi, S., Yoshikawa, D., Okimura, N., Masuda, Y., Katamine, S., and Niwa, M. (2005). Female-specific neuroprotection against transient brain ischemia observed in mice devoid of prion protein is abolished by ectopic expression of prion protein-like protein. Neuroscience 136, 281-287.

Shmerling, D., Hegyi, I., Fischer, M., Blättler, T., Brandner, S., Götz, J., Rülicke, T., Flechsig, E., Cozzio, A., von Mering, C., et al. (1998). Expression of amino-terminally truncated $\operatorname{PrP}$ in the mouse leading to ataxia and specific cerebellar lesions. Cell 93, 203-214.

Spudich, A., Frigg, R., Kilic, E., Kilic, U., Oesch, B., Raeber, A., Bassetti, C.L., and Hermann, D.M. (2005). Aggravation of ischemic brain injury by prion protein deficiency: Role of ERK-1/-2 and STAT-1. Neurobiol Dis 20, 442-449. 


\section{Further Reading}

Caister Academic Press is a leading academic publisher of advanced texts in microbiology, molecular biology and medical research. Full details of all our publications at caister.com

- MALDI-TOF Mass Spectrometry in Microbiology Edited by: M Kostrzewa, S Schubert (2016) www.caister.com/malditof

- Aspergillus and Penicillium in the Post-genomic Era Edited by: RP Vries, IB Gelber, MR Andersen (2016) www.caister.com/aspergillus2

- The Bacteriocins: Current Knowledge and Future Prospects Edited by: RL Dorit, SM Roy, MA Riley (2016)

www.caister.com/bacteriocins

- Omics in Plant Disease Resistance Edited by: V Bhadauria (2016) www.caister.com/opd

- Acidophiles: Life in Extremely Acidic Environments Edited by: R Quatrini, DB Johnson (2016) www.caister.com/acidophiles

- Climate Change and Microbial Ecology: Current Research and Future Trend

Edited by: J Marxsen (2016)

www.caister.com/climate

- Biofilms in Bioremediation: Current Research and Emerging Technologies

Edited by: G Lear (2016)

www.caister.com/biorem

- Microalgae: Current Research and Applications Edited by: MN Tsaloglou (2016) www.caister.com/microalgae

- Gas Plasma Sterilization in Microbiology: Theory, Applications, Pitfalls and New Perspectives Edited by: H Shintani, A Sakudo (2016) www.caister.com/gasplasma

- Virus Evolution: Current Research and Future Directions Edited by: SC Weaver, M Denison, M Roossinck, et al. (2016) www.caister.com/virusevol

- Arboviruses: Molecular Biology, Evolution and Control Edited by: N Vasilakis, DJ Gubler (2016) www.caister.com/arbo

- Shigella: Molecular and Cellular Biology Edited by: WD Picking, WL Picking (2016) www.caister.com/shigella

-Aquatic Biofilms: Ecology, Water Quality and Wastewater Treatment

Edited by: AM Romaní, H Guasch, MD Balaguer (2016)

www.caister.com/aquaticbiofilms

- Alphaviruses: Current Biology

Edited by: S Mahalingam, L Herrero, B Herring (2016)

www.caister.com/alpha

- Thermophilic Microorganisms

Edited by: F Li (2015)

www.caister.com/thermophile
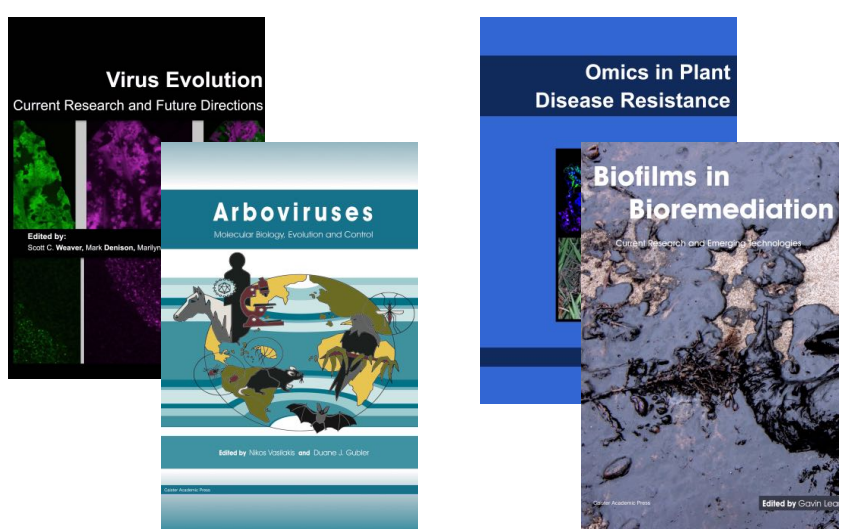
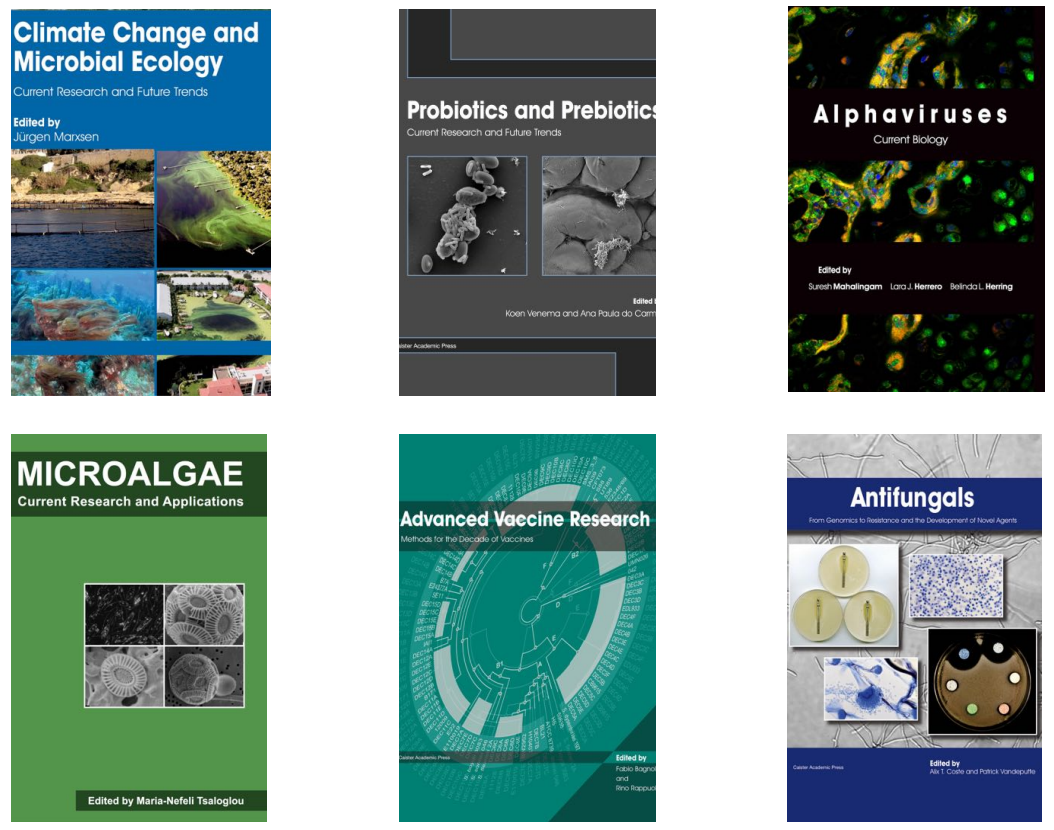

- Flow Cytometry in Microbiology: Technology and Applications Edited by: MG Wilkinson (2015) www.caister.com/flow

- Probiotics and Prebiotics: Current Research and Future Trends Edited by: K Venema, AP Carmo (2015) www.caister.com/probiotics

- Epigenetics: Current Research and Emerging Trends Edited by: BP Chadwick (2015) www.caister.com/epigenetics2015

- Corynebacterium glutamicum: From Systems Biology to Biotechnological Applications

Edited by: A Burkovski (2015)

www.caister.com/cory2

- Advanced Vaccine Research Methods for the Decade of Vaccines

Edited by: F Bagnoli, R Rappuoli (2015)

www.caister.com/vaccines

- Antifungals: From Genomics to Resistance and the Development of Novel Agents

Edited by: AT Coste, P Vandeputte (2015)

www.caister.com/antifungals

- Bacteria-Plant Interactions: Advanced Research and Future Trends Edited by: J Murillo, BA Vinatzer, RW Jackson, et al. (2015) www.caister.com/bacteria-plant

\section{- Aeromonas}

Edited by: J Graf (2015)

www.caister.com/aeromonas

- Antibiotics: Current Innovations and Future Trends

Edited by: S Sánchez, AL Demain (2015)

www.caister.com/antibiotics

- Leishmania: Current Biology and Contro Edited by: S Adak, R Datta (2015) www.caister.com/leish2

- Acanthamoeba: Biology and Pathogenesis (2nd edition) Author: NA Khan (2015)

www.caister.com/acanthamoeba2

- Microarrays: Current Technology, Innovations and Applications Edited by: Z He (2014)

www.caister.com/microarrays2

- Metagenomics of the Microbial Nitrogen Cycle: Theory, Methods and Applications

Edited by: D Marco (2014)

www.caister.com/n2 